\title{
Borges on Bifurcation: Remix at the Interstices of Art and Life
}

\author{
DESIREE D'ALESSANDRO \\ Instructor, Florida Virtual School
}

\begin{abstract}
This paper utilizes "The Garden of Forking Paths" as a starting point to explore Borges's concept of bifurcation and how the act of decision-making in everyday life is closely associated with similar theoretical themes in the Deleuzean notion of multiplicities. These topics then scaffold a self-reflective review of major events from D'Alessandro's life that have shaped her past, present, and likely future. The personal and transformational experiences featured in this case study demonstrate how remix can be embraced as a broad definition and philosophy for life.
\end{abstract}

\section{INTRODUCTION}

"I imagined it infinite... I thought of a labyrinth of labyrinths, of one sinuous spreading labyrinth that would encompass the past and the future and in some way involve the stars."

Dr. Yu Tsun in Borges's "The Garden of Forking Paths" 1

Jorge Luis Borges's "The Garden of Forking Paths" is entrenched with themes regarding diversity of choice in time and how decisions influence ever-unfolding new and divergent outcomes. It is a work that I often reflect on when framing my diverse experiences and creative practice, which have also been sprawling and transforming. This paper briefly explores the theoretical foundations of Borges's story as a starting point and explores remix as a platform that is integral and interconnected to life events and which can be rooted in personal narrative and transformation. I will specifically reflect on Borges's concept of bifurcation and how forking decisions and possibilities are closely associated with similar themes regarding multiplicities in the writings of French philosopher Gilles Deleuze. These concepts will then be utilized to scaffold a self-reflective review of major forking events from my life that have shaped my past, present, and likely future. I embrace filmmaker Kirby Ferguson's broad view of remix and hope that this outline of my experiences will provide the reader with insights that make relevant connections to their own lives. My aim is to inspire contemplation on how remix can become as a life philosophy to navigate everyday existence. 


\section{BORGES ON BIFURCATION}

In "The Garden of Forking Paths," Borges's protagonist, Dr. Yu Tsun, provides a fictional account of events that create a fascinating web of decisions and outcomes told through first-person perspective. Borges weaves these trajectories with consummate skill. Mesmerized as the narrative unfolds, one cannot help but consider how the plot could simultaneously further take shape and shift if different directions were pursued by Dr. Tsun at multiple points. Borges's concept of bifurcation elevates the basic premises of multiple roads one could take and demonstrates how decisions can create diverse futures which proliferate and fork toward endless possibilities. ${ }^{2}$ Scholar Andre Maurois outlines that Borges's fictions are always concerned with processes of striving that lead to discovery and insight; these are archived at times gradually, at other times suddenly. ${ }^{3}$ This speculation on future probability, possibility, and impossibility all symbolically represent features inherent in all human destinies. ${ }^{4}$ Borges's abstract concept of bifurcation is universally relevant and has inspired thinkers, theorists, and philosophers for more than half a century, and it continues to be relevant today. I would like to draw attention specifically to Deleuze, who has directly referenced Borges's writing.

\section{DELEUZE ON MULTIPLICITIES}

Deleuze directly cites Borges in Difference and Repetition and other texts. Deleuze and Felix Guattari recognized Borges's concept of bifurcation and developed their own concept of the rhizome in relation to multiplicities. ${ }^{5}$ The rhizome exists as a transversal vector that functions to assemble multiplicitous outcomes. There is no hierarchy or dominant path; instead, there are multiple paths that exist across a horizontal mode of interaction and put into effect a "maximum communication ... among different levels and above all different directions." ${ }^{\text {In }}$ "The Garden of Forking Paths," Borges presents multiple realities functioning at the same time, as presented in the passage where $\mathrm{Yu}$ Tsun meets with the garden keeper. The "invisible labyrinth of time" and "transparent mystery" are revealed as the garden keeper explains that Ts'ui Pên's endeavors regarding his book and his maze were one and the same. ${ }^{7}$ This potential and emphasis on multiple and parallel possibilities is further cemented with the revealing of the relic of Ts'ui Pên's calligraphy that reads: "I leave to various future times, but not to all, my garden of forking paths." A rhyzomatic connection can then link literature to film, where the role of both the author and the filmmaker is to resolve the dilemma of the fissure of narratives that unfold in order, even as themes of disorder across multiple narratives are brought to the forefront. Deleuze inherently links themes of time, much like Borges, where time consists of a split, a crystal-image that embodies nonchronological passage that is "gushing. . . [and] dividing in two, as splitting." "Deleuze's crystalimage concept can be extended beyond film analysis across a variety of modes and methodologies, outlining a "fragmentation of all linearity." 10 This is particularly applicable to remix videos, as what we see in the crystal is always the perpetual bursting forth of life, of time, in its division and differentiation. ${ }^{11}$

\section{REMIX AND THE RHIZOME}

Elements of remix such as the fragmentation of media and multiple possibilities of expression and communication can be argued as similar to the notion of the rhizome put forth by Deleuze and Guattari. Remix is a creative and intertextual practice that has permeated our popular culture and has become a status quo for contemporary communication and social interaction. ${ }^{12}$ I began writing this essay in February of 2020, during the initial United States quarantine response to COVID-19. 
Since then, the pandemic has afflicted millions of people all over the world. This is a very real international threat, and yet my entire social media feed was filled with humorous memes about toilet paper and social distancing during this time of crisis. It is a complex phenomenon where the coping mechanism of the masses is related to remix and infusing humor into tumultuous times. Among my favorites was a remix utilizing a scene from the film Step Brothers, where Will Ferrell and John C. Reilly embody the human race hysterically responding to continued closures enacted by the World Health Organization and the Centers for Disease Control and Prevention (figure 1). This video closely echoes a Step Brothers remix I generated in my past that uses these comedic characters as respondents to a DMCA violation (figure 2).

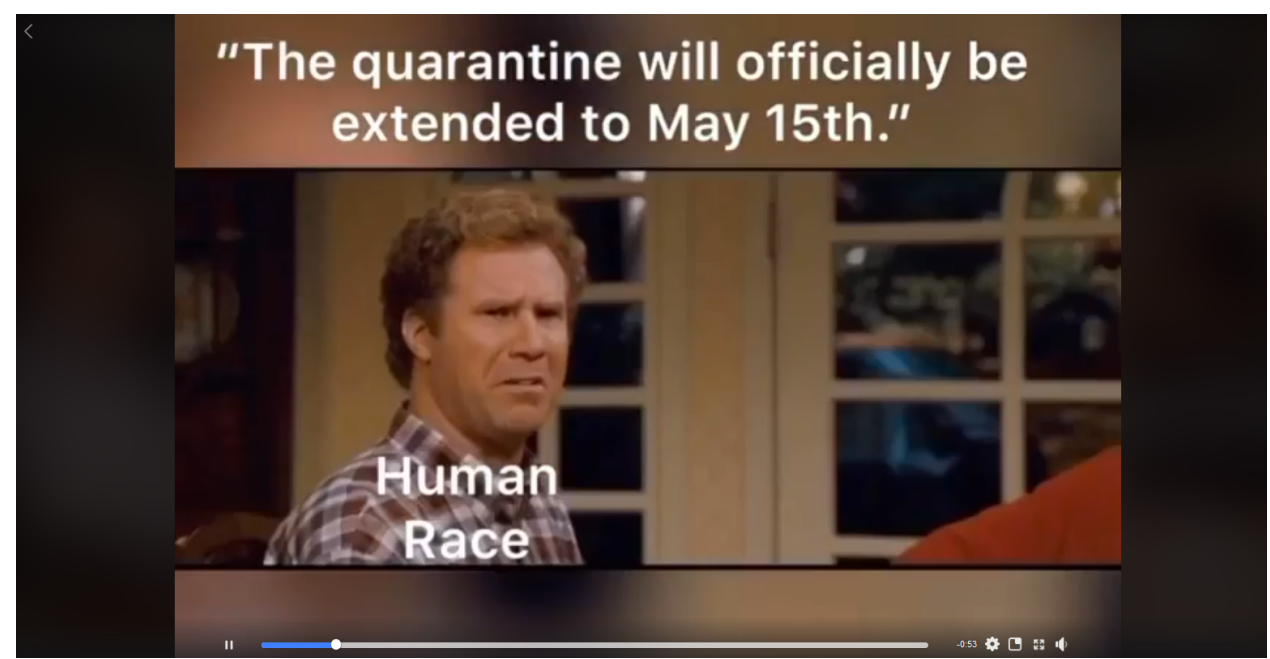

Figure 1. Unknown author, "Step Brothers Quarantine Remix,” 2020, Video via Facebook, courtesy of Jim Skelton. ${ }^{13}$

Particularly astute remix video artists are also raising public awareness of injustices via supercuts that reveal contradictory stances and responses to COVID-19 via major media sources like Fox News $^{14}$ and US President Donald Trump. ${ }^{15}$ As of June 2020, and amid nationwide protests over the killing of George Floyd by Minneapolis police officer Derek Chauvin, remix continues to be a poignant tool. It has been truly powerful to bear witness to people using remix to cross reference acts of protest and racial injustices throughout history and the hypocritical and poorly managed response from President Donald Trump and other officials. ${ }^{16}$ Remix has proven itself to be a powerful tool for political and social critique and dialogue.

In reference to Borges's short story, "The Garden of Forking Paths," my diverse experiences and creative practice embody the sprawling and transformative themes that come out of bifurcating decisions that have arisen in my life. With awareness of the devastating number of Americans who continue to struggle in the wake of COVID-19, I will speak from my personal point of view regarding hardship, aiming to shift the vantage point from the social to the individual. The following select events outlined from my professional and personal life showcase how remix can serve as a guide for being resilient and adaptable in order to navigate difficult times. 


\section{BIFURCATING PATHS: REMIX ADVOCACY \& PEDAGOGY}

In 2010, while enrolled at the University of California, Santa Barbara, I began to employ remix practices in the form of political remix videos. In the process of gathering footage to remix, I was charged with a University-partnered DMCA violation and faced one of the largest conundrums of my entire graduate school journey: Would I accept the punishment and refrain from remixing or would I resist and retaliate? I opted to enter into a world of activism and protest as I fought for the right to utilize remix as an artist and academic. At the onset of this incident, I used a scene from Step Brothers where Will Ferrell and John C. Reilly express outrage in response to the internet ban placed on my computer, as per the DMCA violation penalty policy (figure 2 ).

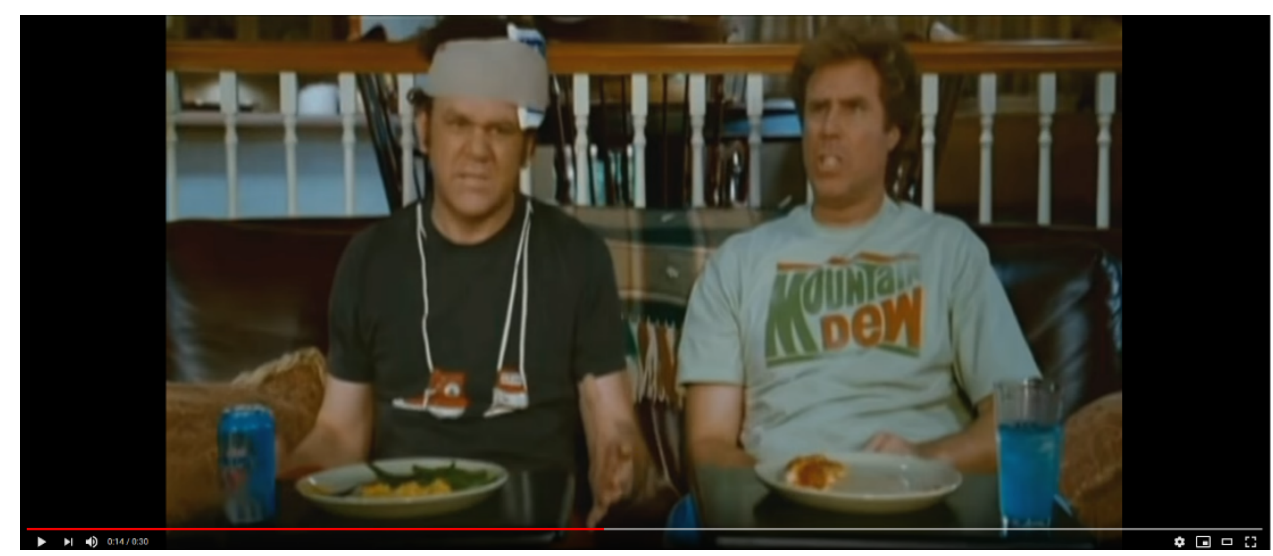

Figure 2. Desiree D'Alessandro, “WHAT?! DMCA Violation (Step Brothers Remix),” 2010, Video via YouTube courtesy of the artist, https://youtu.be/aFx4yTUFtWY.

Another past remix video I would like to highlight is titled "USA Crises: Pure Imagination (Gene Wilder / Willy Wonka Remix)." The late Gene Wilder was an outspoken advocate against the proliferation of profanity and vulgarity perpetuated by Hollywood. I utilized Wilder as a voice of protest addressing a kaleidoscopic view of contemporary US crises that I wish were mere imagination: discreditable presidential candidates, political party tensions, social unrest, racial riots, drone warfare, and the havoc of international bloodshed (figure 3). Looking at America's currently turbulent landscape, the video still strongly resonates today. Over the years, remix has made me mindful of repeating and recurring patterns.

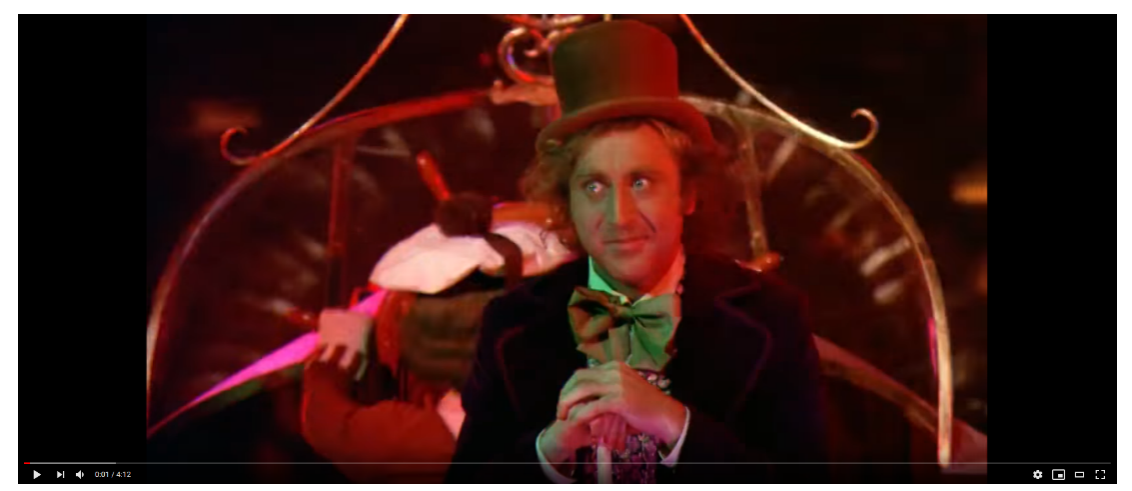

Figure 3. Desiree D'Alessandro, “USA Crises: Pure Imagination (Gene Wilder / Willy Wonka Remix)," 2016, Video via YouTube, courtesy of the artist, https://youtu.be/wSug8Yx1i8Y. 
After practicing remix during my graduate program, I integrated the topic of remix and its historical and conceptual foundations into my COM 242 class curriculum at the University of Tampa, Florida. This was another pivotal moment, where I made a conscious effort to provide opportunities to my students that I had been denied. I presented remix video lectures, fostered workshops, facilitated ongoing and rich dialogue as my students edited, and extended wholehearted support of their entire creative process. One student, Marisa DeRosa, embraced her first attempt at remix in my Digital Citizenship class, juxtaposing Spongebob SquarePants with Fetty Wap (figure 4). Her first remix went viral and to date has amassed 4.5 million views, $36 \mathrm{~K}$ likes, and more than $3.6 \mathrm{~K}$ supportive comments. The fame and feedback that she has received from this work stand as a shining example of the power of remix and the wide potential of remix pedagogical praxes.

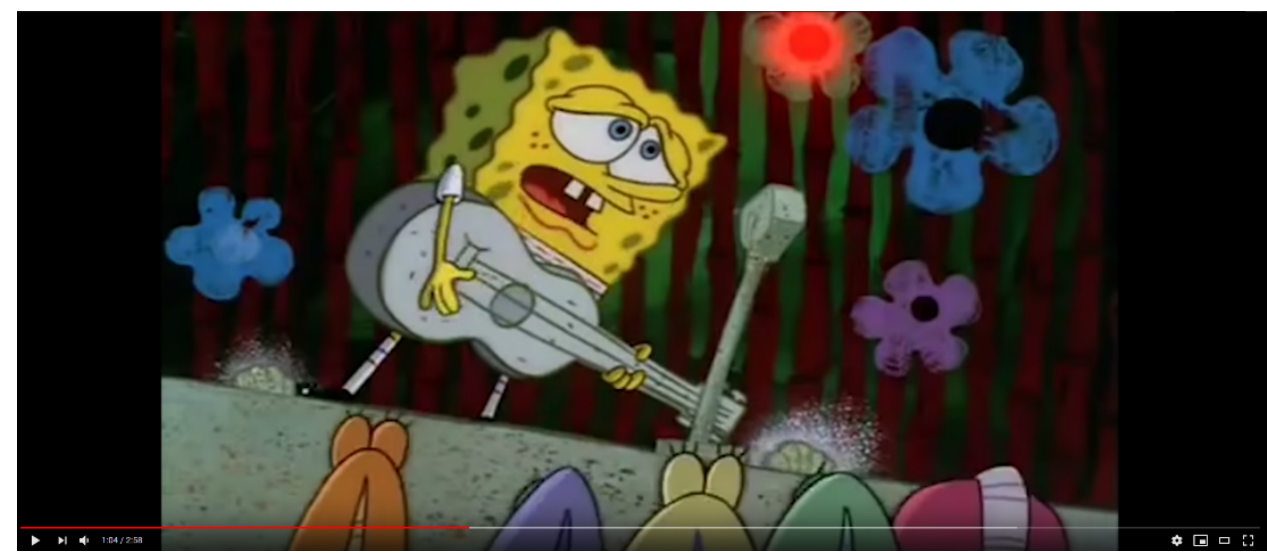

Figure 4. Marisa DeRosa, “Spongebob Raps 679 - Fetty Wap,” 2015, Video via YouTube courtesy of Desiree D'Alessandro, https://youtu.be/B79SrsyWb g.

I moved on to teach online at Florida Virtual School, which entrenched my ties with digital technologies and allowed me to reach a wider and younger audience. The decision also inadvertently made the most significant impact on my life. Most recently, it allowed me to remain safe amid COVID-19. It also enabled me to care for loved ones and develop new personal and intimate relationships that are likely to change my future.

\section{BIFURCATING PATHS: REMIXING ART \& ATHLETICS}

My thoughts on remix as a broad cultural activity continued to evolve, diverge, and meander. With years invested in front of a computer screen exploring digital remix videos, a concerning medical evaluation forced a new forking path in my practice. It became critical that I implement a more physical lifestyle for my overall health and well-being. I shifted away from digital medium-specific studies and focused more on how remix could be utilized as a tool to foster the integration of art and my life. Kirby Ferguson proclaimed that "everything is a remix," in his popularized sequential documentary released between 2010 and 2012. ${ }^{17}$ With this context in mind, drifting into other areas did not seem dramatic. From 2011-2015, I experimented with combining the fields of art and athleticism, specifically boxing. I chose boxing because my father had a deep affinity for it, and he raised me to enjoy boxing with the same passion. I took on the role of an artist-turned-athlete and earned female middleweight amateur boxing titles at a variety of local, state, and national tournaments. This cross-disciplinary route demonstrated a fork in my practice towards 
physicality and performance, where disciplined training became a form of dedicated process art, and the ring was the stage of the performance.
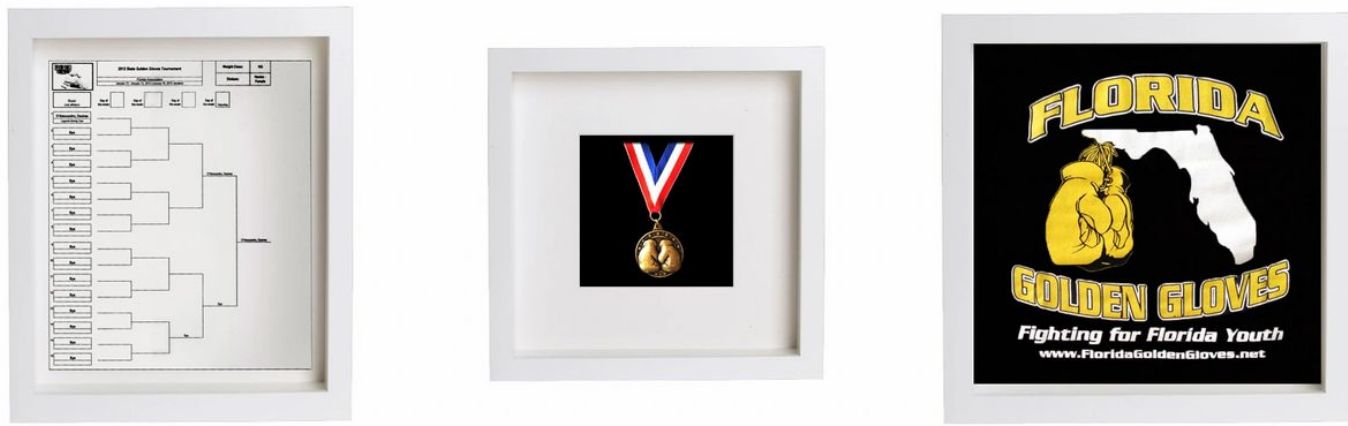

Figure 5. Desiree D'Alessandro, 1,000 Hours of Training, 2012, Found Objects, Dimensions Vary, courtesy of the artist.

\section{BIFURCATING PATHS: CARETAKING, BEREAVEMENT, \& HEALING}

During this period, my father's health rapidly declined. He was diagnosed with terminal liver cancer, and his condition marked the most traumatic forking event in my life. The paths set before me were clear: My father would either spend his final days in a nursing home, or I would take care of him myself with the aid of hospice. I willingly fulfilled the role of my father's in-home caregiver during his final months. The decision highlighted my conviction that all of my life had led to this path: Working from home granted the flexibility to assume multiple roles as daughter, caregiver, artist, educator, and now newly appointed medic as I performed in-home paracentesis treatments to alleviate his discomfort. He passed in January 2017. A year of grieving and reflecting on this challenging experience resulted in the work Lightboxer.

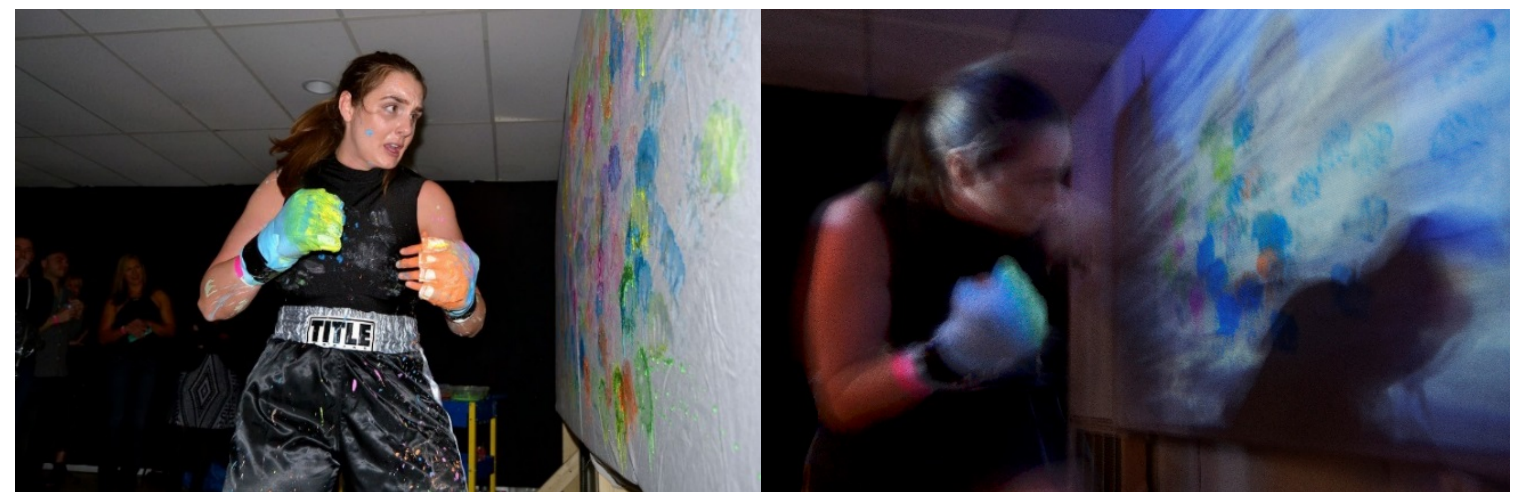

Figure 6. Desiree D'Alessandro, Lightboxer, 2018, Performance and Projection Installation, 11'x4' Canvas, courtesy of Nicholas Tangredi.

In Ways of Seeing, art critic John Berger asserts that "art profoundly allows us to share the artist's experience of the visible."18 In this sense, Lightboxer was a final memorial tribute to my father. I combined action painting on an 11-foot canvas, performance through boxing, and video projection. I revived the boxing gear I formerly donned for my 2014 Women's National Golden 
Gloves title and wore boxing wraps that I crafted from my father's sterility sheets. The video projection of water during the rounds symbolized where the ashes of my father, brother, and mother were laid to rest in Florida's Hillsborough River. Audio excerpts filled the space between the rounds. These featured fragments from the last recording I possess of my father and me recalling fond memories. I titled the piece, Lightboxer, as a play on the term shadowboxer. The title references Joseph Cornell's shadow boxes, and the work is a type artifact that preserves my history with my father. Moreover, the concept of shadowboxing or throwing punches is a form of training in the process of finding my own light in the darker paths of life. Everyone must seek their own light while facing life's trials. There is no ringside; we are all in this fight. It is the fight that counts: the willpower to remain strong, to persevere, and to live well.

\section{CONVERGING PATHS AND CONCLUSION: REMIX AS A LIFE PHILOSOPHY}

As I outline my past life experiences, my mind once again wanders to Dr. Yu Tsun in the "The Garden of Forking Paths." As Tsun's decisions unfold, the outcomes could have changed entirely if different or delayed actions were taken at multiple points in the narrative. The same could be said for my life and how I have navigated grad school, teaching, my creative practice, and personal struggles. All of these events, and my responses to them, have led me to where I am and shaped who I am today.

I recognize remix as a singular and collective tool for creative praxes and decision-making. If adopted as a life philosophy, remix provides a powerful foundation for sentimental and meaningful connections across time and space and at the intersection of art and life. In Borges's "The Garden of Forking Paths," Yu Tsun realizes that "every one imagined two works; to no one did it occur that [Ts'ui Pên's] book and the maze were one the same." 19 It is my contention that remix as a creative practice and remix as a way of life can also be understood as one and the same. Remix can permeate and imbue decisions and also be utilized as a mechanism for coping with change and loss. Peggy Phelan explains how, in our reflection upon the absence of others, we must redefine ourselves: "The real is the absence of them and we are living representations [or remixes] of that loss." ${ }^{20}$ This is very similar to Borges's highlighting in Ts'ui Pên's letter how familial bloodlines transmit with each successive generation and "each new individual adds a chapter or corrects with pious care the pages of [their] elders." ${ }^{21}$ Also true in Ts'ui Pên's letter is the fascinating notion that sometimes complex networks of paths in the labyrinth of life can eventually converge. ${ }^{22}$ Borges's interest was how art - and by extension remix - represents a tool that could be used to shape and relate to people. ${ }^{23}$ These potentialities of how people can be shaped or transformed have also been referenced by Gilles Deleuze, particularly in his concepts of "lines of flight" and "a people to come." ${ }^{24}$ Ultimately, we can approach uncertain decisions and forking paths that lie ahead in life with more flexibility and confidence if we embrace the possibilities of remix.

\section{ACKNOWLEDGEMENTS}

I extend my deepest thanks to colleagues Diran Lyons, Maureen Cox-Brown, and Joanne Steinhardt for their thoughts and feedback related to the development of this essay. I cherish our deep conversations regarding remix praxes and art theory and respect their invaluable insights. Thank you also to Eduardo Navas, xtine burrough, and Owen Gallagher for the additional guidance and for the opportunity to publish with Media-N. I would like to thank Nicholas Tangredi and Melissa 
Tangredi, my newfound family, whom I love dearly. I look forward to embracing our future together. Lastly, I offer thanks to my late father, Victor D'Alessandro, my late brother, Domonick D'Alessandro, and my late mother, Denise D'Alessandro. Not a day goes by where I do not miss you all immensely. I am grateful for the experiences that shaped me, and I promise to continue to honor our family name and make you all proud.

\section{ENDNOTES}

1. Jorge Luis Borges, "The Garden of Forking Paths," in Labyrinths: Selected Stories and Other Writings, eds., Donald A. Yates and James E. Irby (Cambridge: New Directions Publishing Co., 1962), 34.

2. Borges, "The Garden of Forking Paths," 37.

3. Andre Maurois, "Preface and Introduction," in Labyrinths: Selected Stories and Other

Writings, eds., Donald A. Yates and James E. Irby (Cambridge: New Directions Publishing Co., 1962), 12.

4. Andre Maurois, "Preface and Introduction," 5-6.

5. Gilles Deleuze and Felix Guattari, A Thousand Plateaus: Capitalism and Schizophrenia, trans.

Brian Massumi (Minneapolis: University of Minnesota Press, 1987), 7.

6. Ronald Bogue, Deleuze's Way: Essays in Transverse Ethics and Aesthetics (Aldershot, UK:

Ashgate Publishing, 2007), 2.

7. Borges, "The Garden of Forking Paths," 36.

8. Borges, "The Garden of Forking Paths," 36.

9. Gilles Deleuze, Cinema 2: The Time-Image, trans., Hugh Tomlinson and Robert Galeta

(Minneapolis: University of Minnesota Press, 1989), 81.

10. Deleuze, Cinema 2: The Time-Image, 49.

11. Deleuze, Cinema 2: The Time-Image, 91.

12. Stefan Stefanov, "Intertextuality vs Remix," Remix Culture: A New Cultural Paradigm, accessed August 9, 2020, http://remix.cheeseus.org/index.php/defining-remix/17-intertextualityvs-remix.

13. Jim Skelton, Facebook, accessed 02 January 2021,

https://www.facebook.com/jim.skelton.167/videos/3242837712415810/

UzpfSTUxNzYyMjUzNDoxMDE1Nzg3OTUzMzgxNzUzNQ.

14. Ed Mazza, "Stunning Supercut Exposes Fox News' Dangerous Hypocrisy on Coronavirus," HuffPost, last modified March 18, 2020, https://www.huffpost.com/entry/fox-news-coronavirussupercut-video_n_5e71ac69c5b6eab7793e9bf6.

15. Lee Moran, "Damning Supercut Exposes One of Donald Trump's Favorite COVID-19 Lies," HuffPost, last modified October 24, 2020, https://www.huffpost.com/entry/donald-trump-dailyshow-supercut-coronavirus-lie_n_5f93e359c5b68dbe93f7929f.

16. Diran Lyons, "Trump and the Descent into Dictatorship (Death of Democracy 2020 Remix)," YouTube, last modified October 5, 2020, https://youtu.be/flGmNmr6pCU.

17. Kirby Ferguson, "Everything Is a Remix Remastered (2015 HD)," YouTube video, 37:30, accessed August 9, 2020, https://youtu.be/nJPERZDfyWc.

18. John Berger, Ways of Seeing, (London: Penguin Books, 1990), 10.

19. Borges, "The Garden of Forking Paths," 36.

20. Peggy Phelan, Unmarked: The Politics of Performance, (New York: Routledge, 1993), 12.

21. Borges, "The Garden of Forking Paths," 37. 
22. Borges, "The Garden of Forking Paths," 37.

23. Noah Wardrip-Fruin and Nick Montfort, eds., The New Media Reader (Cambridge: The MIT Press, 2003), 29.

24. Deleuze and Guattari, A Thousand Plateaus, 9.

\section{REFERENCES}

Berger, John. Ways of Seeing. London: Penguin Books, 1990.

Bogue, Ronald. Deleuze's Way: Essays in Transverse Ethics and Aesthetics. Aldershot, UK: Ashgate Publishing, 2007.

Borges, Jean Luis. "The Garden of Forking Paths." In Labyrinths: Selected Stories and Other Writings. Edited by Donald A. Yates and James E. Irby, 31-9. Cambridge: New Directions Publishing Co., 1962.

D'Alessandro, Desiree. "WHAT?! DMCA Violation (Step Brothers Remix).” YouTube video, 00:30. Accessed August 9, 2020. https://youtu.be/aFx4yTUFtWY.

"USA Crises: Pure Imagination (Gene Wilder / Willy Wonka Remix)."

YouTube video, 04:12. Accessed August 9, 2020. https://youtu.be/wSug8Yx1i8Y.

Deleuze, Gilles. Cinema 2: The Time-Image. Translated by Hugh Tomlinson and Robert Galeta. Minneapolis: University of Minnesota Press, 1989.

Deleuze, Gilles and Felix Guattari. A Thousand Plateaus: Capitalism and Schizophrenia.

Translated by Brian Massumi. Minneapolis: University of Minnesota Press, 1987.

DeRosa, Marisa. "Spongebob Raps 679 - Fetty Wap.” YouTube video, 02:59. Accessed August 9, 2020. https://youtu.be/B79SrsyWb_g.

Ferguson, Kirby. "Everything Is a Remix Remastered (2015 HD).” YouTube video, 37:30. Accessed August 9, 2020. https://youtu.be/nJPERZDfyWc.

Lyons, Diran. Trump and the Descent into Dictatorship (Death of Democracy 2020 Remix). YouTube video, 01:54. Accessed August 9, 2020. https://youtu.be/flGmNmr6pCU.

Maurois, Andre. "Preface and Introduction." In Labyrinths: Selected Stories and Other Writings. Edited by Donald A. Yates and James E. Irby, 5-30. Cambridge: New Directions Publishing Co., 1962.

Mazza, Ed. "Stunning Supercut Exposes Fox News' Dangerous Hypocrisy On Coronavirus." HuffPost. Last modified March 18, 2020. https://www.huffpost.com/entry/fox-newscoronavirus-supercut-video_n_5e71ac69c5b6eab7793e9bf6.

Moran, Lee. "Damning Supercut Exposes One of Donald Trump's Favorite COVID-19 Lies." 
HuffPost. Last modified October 24, 2020. https://www.huffpost.com/entry/donaldtrump-daily-show-supercut-coronavirus-lie_n_5f93e359c5b68dbe93f7929f.

Phelan, Peggy. Unmarked: The Politics of Performance. New York: Routledge, 1993.

Stefanov, Stefan. "Intertextuality vs Remix," Remix Culture: A New Cultural Paradigm, Accessed August 9, 2020. http://remix.cheeseus.org/index.php/defining-remix/17intertextuality-vs-remix

“Step Brothers Quarantine Remix.” Facebook video, 01:00. Accessed August 9, 2020. https://www.facebook.com/jim.skelton.167/videos/3242837712415810/UzpfSTUxNzYy MjUzNDoxMDE1Nzg3OTUzMzgxNzUzNQ.

Wardrip-Fruin, Noah, and Nick Montfort, eds. The New Media Reader. Cambridge: The MIT Press, 2003.

\section{AUTHOR BIO}

Desiree D'Alessandro is an award-winning artist and educator with a decade of experience in public, private, and for-profit education. D'Alessandro specializes in digital and interdisciplinary media. Her practice explores the integration of fields involving critical theory, performance art, interactive installation, and open source video. Her works have been exhibited nationally at museums and galleries within New York, California, Florida, Illinois, New Mexico, and Massachusetts. Her works have also been exhibited internationally at lectures, residencies, festivals, and alternative venues in the United Kingdom, France, Spain, Germany, Canada, and Switzerland. Her critical writings have been published in books and academic journals and she has presented and chaired sessions at diverse conferences across the nation.

Desiree D'Alessandro is a contemporary artist from Tampa, Florida. She has a Master of Fine Arts in New Genres and Extended Praxes from the University of California, Santa Barbara. She was a UC Regents Special Fellow, UC Humanities Research Institute (UCHRI) Scholar, and Humanities, Arts, Science, and Technology Advanced Collaboratory (HASTAC) Scholar. 